\title{
EVALUATION OF GEOMECHANICAL FEATURES AND STABILITY FOR THE RECOMMENDATIONS AND REHABILITATION OF THE HUMBERTO MOLINA HOSPITAL, ZARUMA, EL ORO, ECUADOR
}

\author{
PAÚL CARRIÓN-MERO ${ }^{1,2}$, JOSELYNE SOLÓRZANO ${ }^{1,2}$, MIGUEL ÁNGEL CHÁVEZ ${ }^{3}$, \\ ROBERTO BLANCO $^{4}$, FERNANDO MORANTE-CARBALLO ${ }^{1,5,6}$, MARIBEL AGUILAR $^{3}$ \\ \& JOSUÉ BRIONES-BITAR ${ }^{3}$ \\ ${ }^{1}$ Centro de Investigación y Proyectos Aplicados a las Ciencias de la Tierra, \\ ESPOL Polytechnic University, Ecuador \\ ${ }^{2}$ Facultad de Ingeniería Ciencias de la Tierra, ESPOL Polytechnic University, Ecuador \\ ${ }^{3}$ BIRA Bienes Raíces S.A., Ecuador \\ ${ }^{4}$ Facultad de Geología y Minas, Instituto Superior Minero-Metalúrgico de Moa, Cuba \\ ${ }_{5}^{5}$ Facultad de Ciencias Naturales y Matemáticas (FCNM), Escuela Superior Politécnica del Litoral, Ecuador \\ ${ }^{6}$ Facultad de Ciencias Naturales y Matemáticas (FCNM), ESPOL Polytechnic University, Ecuador
}

\begin{abstract}
Zaruma is a city with a mining tradition, located at $1,200 \mathrm{~m}$ above sea level, with natural conditions of high slopes. The existence of galleries under the city centre, originated by old and illegal mining works, has created conditions that impact the mining-society relationship of a technical-social nature, with concern about subsidence city's urban area. The areas of the Humberto Molina Hospital and its surroundings, such as the SJ Bosco School, have been affected by different geodynamic events, which has damaged infrastructure. The aim of this research is to assess the study area through geotechnical surveying, processing laboratory information, and direct field observation, using the approach of pre-design proposals containing technical solutions to ensure the safety of buildings. The methodology used consists of: (i) information processing and field surveys; (ii) drilling and pits work for sampling and determination of in-situ properties and laboratory work; (iii) interpretation of the results obtained, assessment of stability conditions through Spencer's method and consideration of the influence of underground work; (iv) analysis of susceptibility to slippage using the methodology of various authors; and (v) proposal of the pre-design of the technical security solutions. The study verified that the stability of the works are influenced, both by the physiographic factors and the incidence of nearby illegal underground work. Slope stability can be aggravated in extreme situations by seismic action, heavy rainfall, and migration of underground voids in the direction of the works. Susceptibility analysis determined that the terrain is in a stable condition, as the soil studied was categorized as medium to very good quality. Among the recommendations for the remediation of the Humberto Molina Hospital, it is suggested control of the drainage of rainwater and wastewater, use of vegetation, change of current fill, strengthening with concrete, and other basic considerations regarding building structures should be undertaken, associated with direct observation and geotechnical studies.
\end{abstract}

Keywords: slope stability, geodynamic phenomena, hospital, geomechanics, susceptibility.

\section{INTRODUCTION}

In geological engineering, one of the most important topics is the slopes design, because it is immersed in almost every building, such roads, canals, or tunnels, in the case of mining extractions [1]. A slope can be of an artificial origin, made by man, or of natural origin, as a product of the material erosion and deposit [2]. Different factors influence, cause and trigger slope instability, the most common are excavations, soil saturation by water discharge and overloads [3]. One of the anthropic activities that form part of these factors is mining, which is booming. 
Many cities have developed in conjunction with mining [4], playing an important role in global economic growth [5], such as the case of the state of Hidalgo in Mexico, which has 500 years of experience and is a very important mining entity in the country [6]. Similarly, there are cases where mining has created problems globally. When this activity is carried out underground, it generates gaps or voids that could cause collapses instantly, while the material is extracted, or 100 years or more after the extraction performed [7]. Mining subsidies from exploitations are one of the main causes of induced deformations on the ground [4]. One of the most controversial mining subsidence examples is the one located in Kiruna, northern Sweden, built by the state-owned mining company LKAB, where cracks have been recorded showing subsidence problems due to excessive iron mining [8].

In Ecuador, a case of subsidence is registered in Zaruma, located in the southwest of the country. Within El Oro province, at an altitude of 1200 m.a.s.l. Due to its mining history, which occurs in the mining district Zaruma-Portovelo, the most important in Ecuador, it was declared a cultural heritage site in 1990 [9]. Zaruma is located on a large epithermal low sulfidation deposit, with structures preferably N-S filled by hydrothermal fluids, forming important quartz veins with major occurrences of gold, silver, and copper. These veins travel long distances (extending for $12 \mathrm{~km}$ from Minas-Nuevas in the north, to El Tablon in the south), framed between two regional faults located to the North (Busa-Palestina) and south (Piñas-Portovelo) with direction WNW-ESE. Also, the veins are located several hundred meters deep and many of them in such a way that the exploitation carried out by informal miners in search of the precious metal has caused their labors to be close to the surface, generating areas prone to subsidence in various parts of the city. Nearly $60 \mathrm{~km}$ of mining galleries have been discovered that have preyed on the bowels of the city because of informal mineral extraction. All this has caused the buildings to lose stability in their foundations [10], as in the case of the La Inmaculada School sinkhole that has been the most serious and epicenter sign of Decree 158, which declared the state of exception to combat illegal mining.

To the SW of Zaruma is located the hospital Humberto Molina, which was evacuated by an emergency declaration that the COE provincial (Emergency Operations Committee) issued on November 18, 2017, after verifying that the dimensions of the cracks registered in the infrastructure in previous years had increased in size after an earthquake occurred (magnitude $5.8^{\circ}$ ) on November 17, 2017, with the epicenter in Balao, located $137 \mathrm{~km} \mathrm{NW}$ of Zaruma.

This work's aim is to geotechnically evaluate the Humberto Molina Hospital area, through the collection and processing of geotechnical information, laboratory, and direct field observation, for the pre-design approach proposals containing technical solutions to ensure the building safety. With the aforementioned aspects, is illegal mining the problem that has caused instability in the slope on which the Humberto Molina Hospital is built, putting at risk this medical infrastructure, health and safety of the inhabitants of Zaruma, Atahualpa and Portovelo?

\section{GEOGRAPHICAL AND GEOLOGICAL ENVIRONMENT}

The Humberto Molina Hospital is located to the $\mathrm{S}$ of the Zaruma canton, El Oro province, at latitude $3^{\circ} 41^{\prime} 30^{\prime \prime} \mathrm{S}$ and length 79॰36'36" W, in the state-owned Don Bosco neighborhood (Fig. 1). The Hospital was a reference center for the Zaruma, Portovelo, and Atahualpa cantons, which registered about 45,000 inhabitants [11]. The Risk Management Secretary [12] determined that the hospital is in an instability area due to the presence of slopes $>50^{\circ}$, a factor that generates reptation in the direction of SE and SW.

The study area is located on the Portovelo unit, consisting mainly of andesite rocks, volcanic tuffs, and breccia of andesite clasts that in their final weathering phase have formed 
powerful soils (thicknesses between 20 to $25 \mathrm{~m}$ ) of clay, sandy and sandy-clayey type of reddish-gray to dark gray color, highly unstable, which when in contact with heavy rainfall saturates, cause subsidence that affects the hospital infrastructure [12]. Besides, in the NW region of the study area (Fig. 1) there is a filling area, which causes sinking problems.

\section{METHODOLOGY}

To achieve the aim, office work was combined with fieldwork and interpretation, described below in 4 phases (Fig. 2).

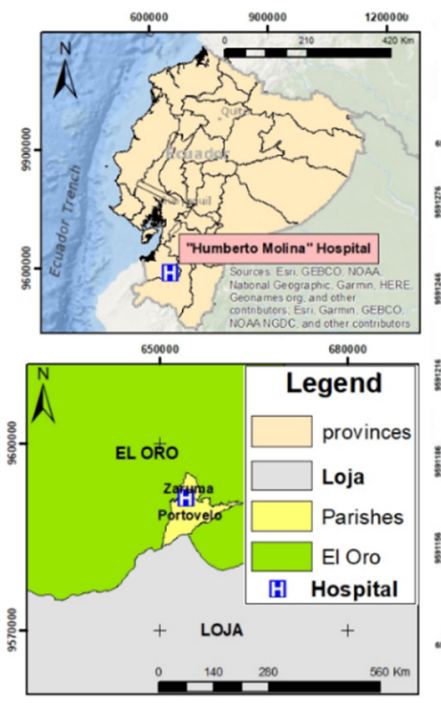

\section{Location map and geology "Humberto Molina" Hospital}

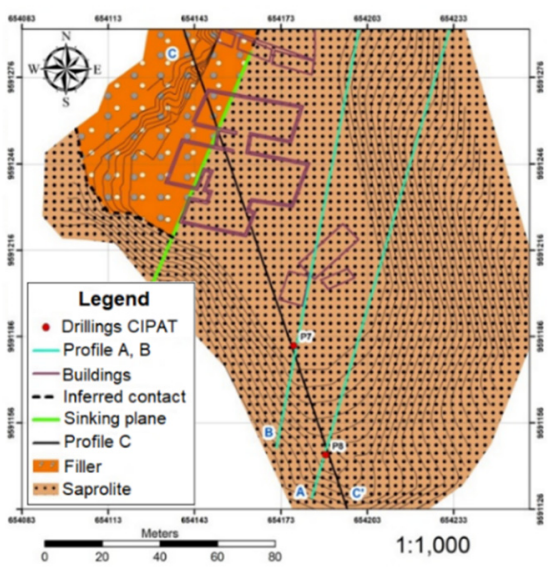

Figure 1: Location map and geology of Humberto Molina Hospital.
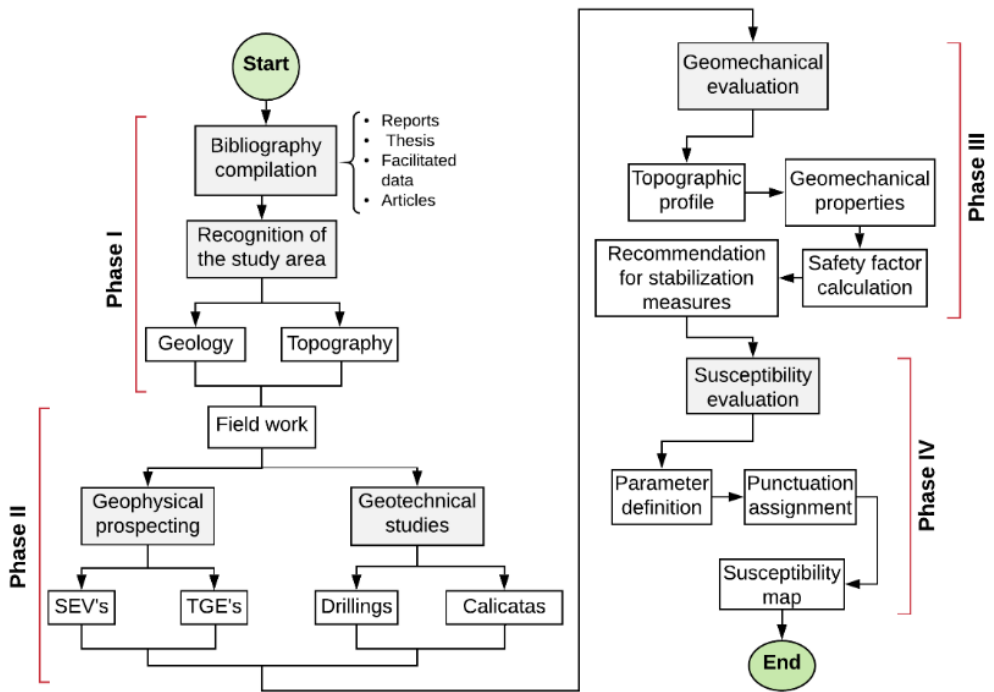

Figure 2: Flowchart of the methodology used in this study. 


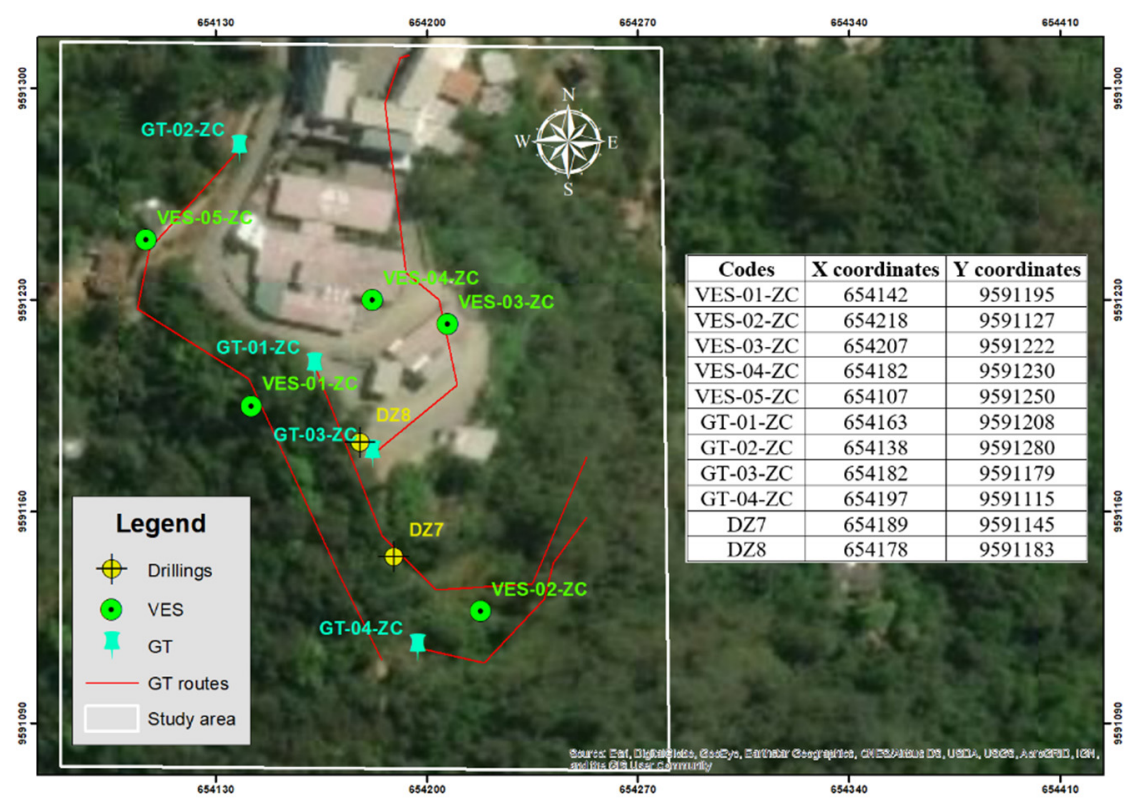

Figure 3: Location of VES, GT and drilling performed in the study area.

\subsection{First phase}

Information was collected from reports made by the Risk Management Secretary, the Public Health Ministry, the Mining Control Regulatory Agency, scientific articles and theses. With this bibliographic base, field recognition was carried out, the geology of the sector and surveying with differential GPS was carried out.

\subsection{Second phase}

In the field, the places that presented terrain conditions without great topographic variation were selected, to carry out geophysical prospecting.

\subsubsection{Vertical Electrical Sounding (VES) and Geoelectrical Tomography (GT)}

5 VES were made with Schlumberger configuration, and 4 GT with Wenner configuration (Fig. 3), both procedures with an opening between $5 \mathrm{~m}$ electrodes, using ABEM terrameter SAS 1000 equipment. The resistivity information obtained in the VES was processed in the software IPI2win while the GT data was processed in the software RES2DINV.

\subsubsection{Drillings and calicatas}

Based on the geophysical studies, the two perforations DZ7 and DZ8 were planned, 10 and $15 \mathrm{~m}$ deep respectively. The geological-geotechnical record of the drilling witnesses was carried out, determining the lithology, thicknesses, structures, and massif quality. Three calicatas were carried out inside the Hospital, with depths between 40 and $50 \mathrm{~cm}$, allowing the analysis and verification of the lithology just below the civil works, as well as their respective correlation for the concrete analysis thicknesses and filling. Besides, material samples were taken with Shelby tubes for subsequent laboratory tests. 


\subsection{Third phase}

With the drilling information and the previous reports, the topographic profiles were made from the contour lines and processed in the SLIDE software, altogether with the geomechanical properties of saprolite. Obtaining the slip surface, the safety factor is calculated using Spencer method.

\subsection{Fourth phase}

For the slippage susceptibility, analysis was applied with a theoretical-practical approach based on the criteria of experts (Suárez, Nicholson, Transportation Research Board and González) [13].

\subsubsection{Parameter definition}

The conditions present in the study area were evaluated and a preliminary characterization was made, based on the results previously obtained in the field visits and studies carried out in the area. This allowed us to obtain criteria on the sectors most prone to a mass movement and the factors that can most influence it. From this, the geotechnical stations were chosen (Fig. 4) and the main parameters to be considered in the slippage susceptibility analysis were defined.

\subsubsection{Score assignment}

The parameters evaluated for slippage susceptibility are detailed in Table 1.

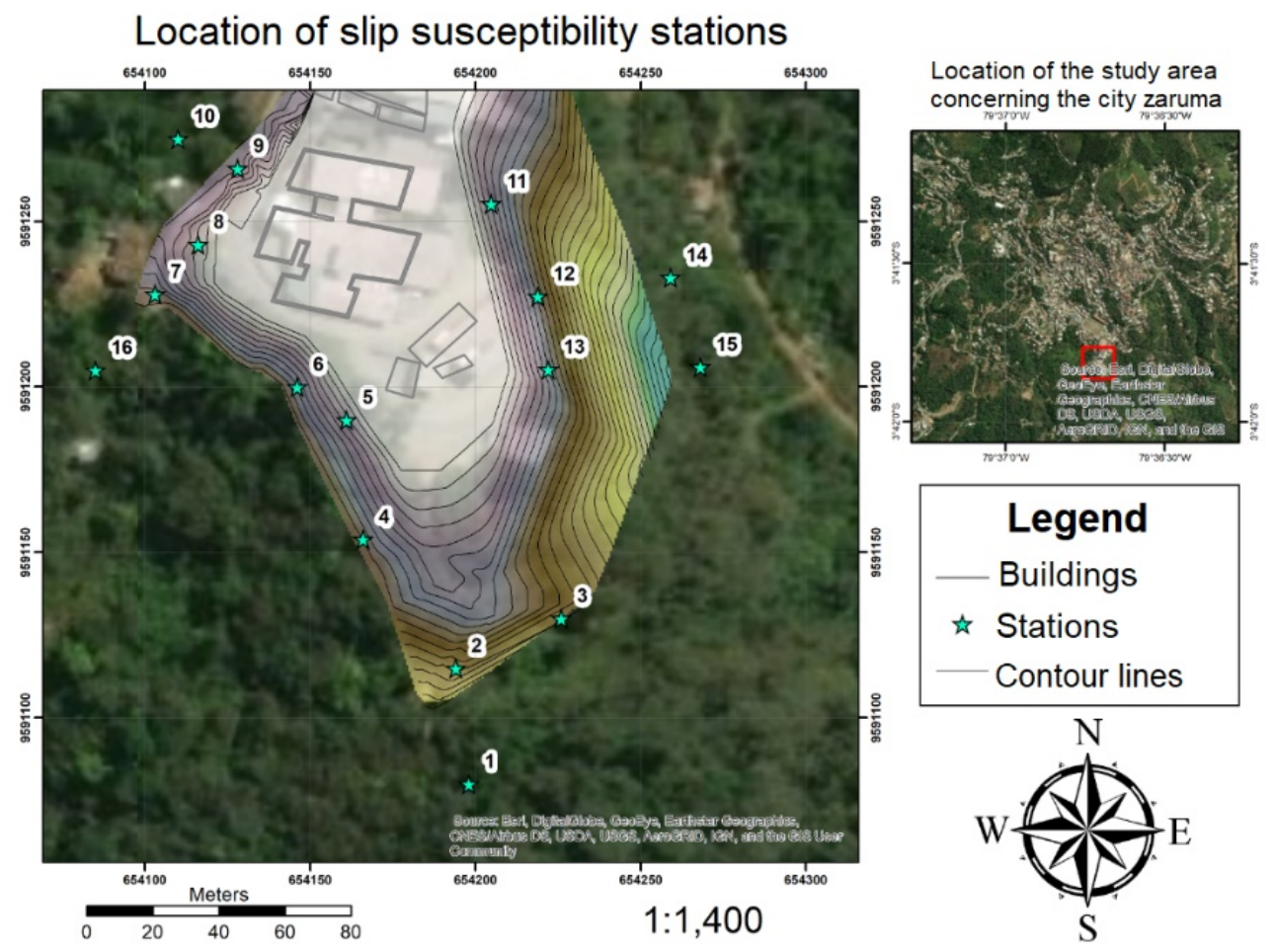

Figure 4: Location of the geomechanical stations with respect to the contour lines. 
Table 1: The scores assigned to each parameter concerning the soil.

\begin{tabular}{|l|c|}
\hline Main parameters & Score assigned in the slippage susceptibility analysis (S.S) \\
\hline Lithology & Up to 4.0 \\
\hline Geological structure & Up to 4.0 \\
\hline Morphometry & Up to 4.0 \\
\hline Weathering rank & Up to 4.0 \\
\hline Water presence & Up to 3.0 \\
\hline Vegetable cover & Up to 3.0 \\
\hline Seismic & Up to 4.0 \\
\hline
\end{tabular}

\section{RESULTS}

\subsection{Structure identification and tunnels}

During the field trips made in the study area, the main geological structures were identified, determining the boundary between the filler material on the west side and saprolite on the east side of the hospital, with structural measures of N203\% $/ 73^{\circ} \mathrm{SE}$ (Fig. 5). Also, the tunnels survey near the area was carried out, finding a tunnel to the SW of the area with direction $\mathrm{N} 120^{\circ}$, approximately $24 \mathrm{~m}$ deep, $1.60 \mathrm{~m}$ high and $0.80 \mathrm{~m}$ wide. Weathered volcanic rock could be observed (volcanic transformed into saprolite) with different families of decimetric fractures, filled with quartz with centimeter thickness. Intense fracturing was evident, highlighting three families of main discontinuities, with structural measures of $\mathrm{N} 3^{\circ} / 78^{\circ} \mathrm{SE}$, N202 $/ 34^{\circ} \mathrm{NW}, \mathrm{N} 98^{\circ} / 80^{\circ} \mathrm{SW}$ (Fig. 5).

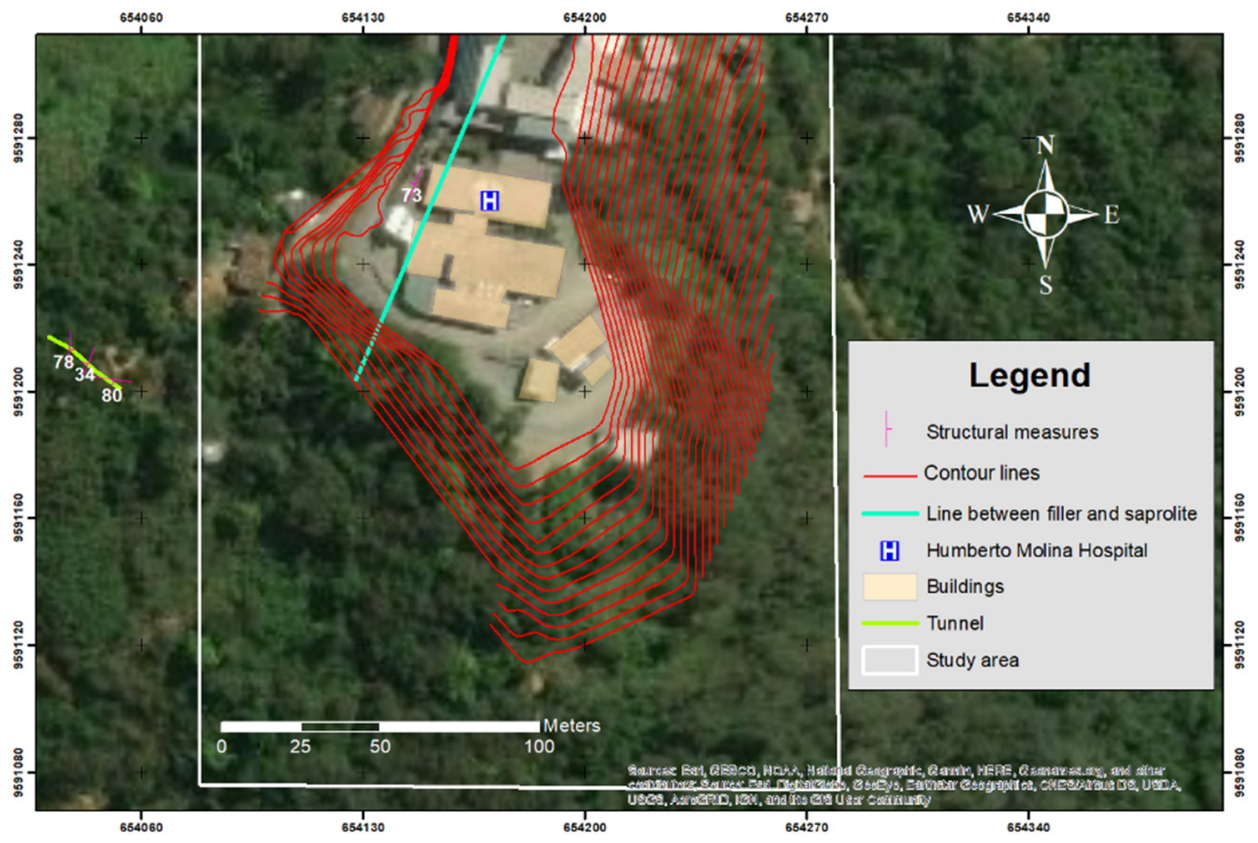

Figure 5: Structures measured map in the study area. 


\subsection{Geology and geophysics}

Table 2 shows the lithologies based on the resistivities determined in the VES and the GT.

Based on the areas of interest located in the geophysical prospecting, the two drillings DZ7 and DZ8 were made (Fig. 3), 10 to $15 \mathrm{~m}$ deep respectively (Figs 6 and 7), to directly determine the lithology below the study area.

Table 2: Interpretation of the lithology based on VES and GT.

\begin{tabular}{|c|c|l|}
\hline Resistivity ( $\mathbf{\Omega m})$ & Depth $(\mathbf{m})$ & Interpretation \\
\hline $1-7$ & 1 & Soil \\
\hline $7-25$ & $1-11$ & Very saturated saprolite \\
\hline $25-80$ & $1-7$ & Saturated saprolite \\
\hline $80-200$ & $1-21$ & Slightly saturated saprolite \\
\hline $200-550$ & $9-20$ & Fractured saprolite \\
\hline $550-850$ & $11-20$ & Saprolite \\
\hline
\end{tabular}

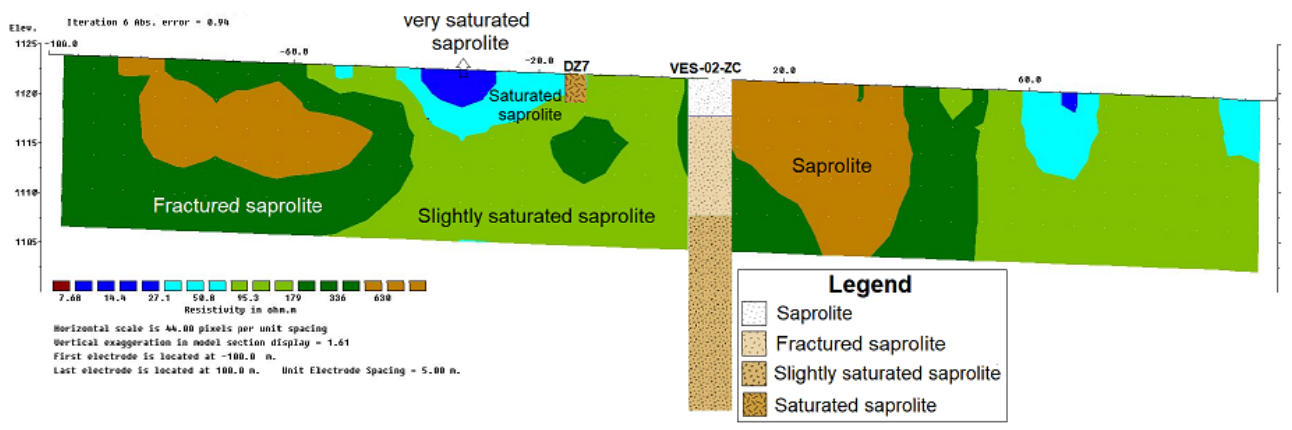

Figure 6: Correlation between tomography (GT-01-ZC), sounding (VES-02-ZC) and DZ7 drilling.

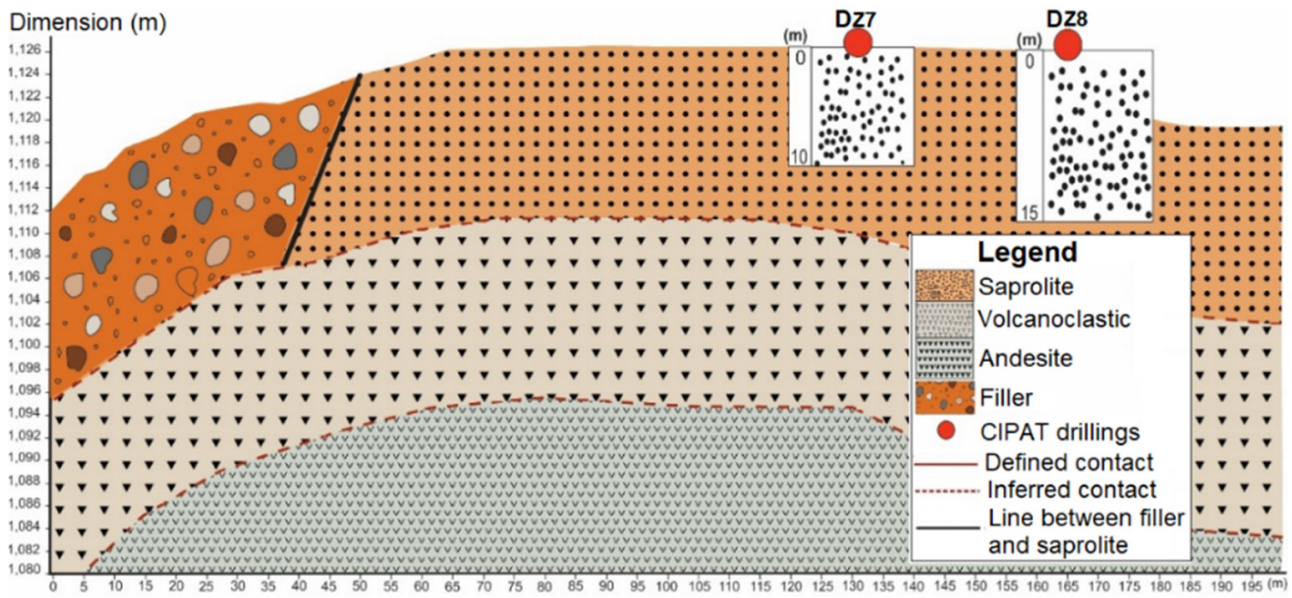

Figure 7: Relationship between perforations and geological profile. 


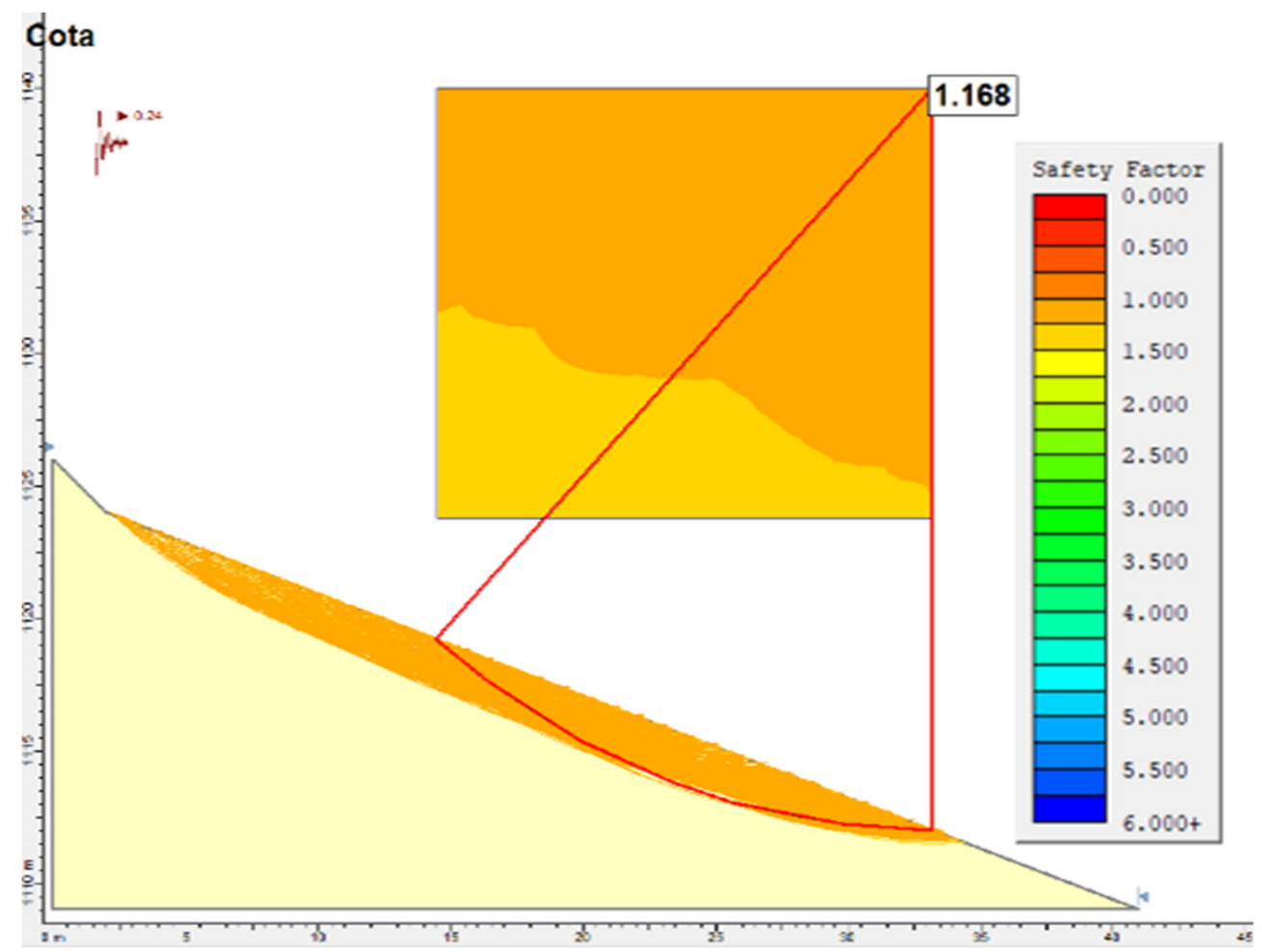

Figure 8: Safety factor calculation with seismic coefficient in the slide software.

As a result, the presence of fully weathered saprolite was obtained, colored between reddish-brown, orange-brown until yellowish-brown, from very fine granulometry on the surface to medium-coarse granulometry at the end of the drillings.

\subsection{Safety factor}

Several runs were performed on the SLIDE software using the Spencer method to calculate the safety factor, considering the seismic coefficient, the value of 1,168 was determined as the lowest (Fig. 8).

\subsection{Susceptibility map}

Zoning of the study area was carried out, based on the extreme water saturation situation in the slope, assigning this parameter the highest assessment (Table 3). Subsequently, heat maps were created where the behavior of the terrain could be observed according to its slippage susceptibility (S.S) grade. Finally, the susceptibility map was obtained (Fig. 9), where the yellow zone represents category III, correspondingly to stable conditions and systematic monitoring. While the orange zone that corresponds to category IV, it covers most of the contour lines of the study area, which represents potentially unstable conditions. 
Table 3: Classification of susceptibility to slippage with a maximum water saturation parameter.

\begin{tabular}{|c|c|l|}
\hline Station & S.S grade & Observations \\
\hline 1 & 9.5 & Preponderantly stable conditions, there must be monitoring \\
\hline 2 & 12 & Potentially unstable conditions \\
\hline 3 & 12.5 & Potentially unstable conditions \\
\hline 4 & 12.5 & Potentially unstable conditions \\
\hline 5 & 10.5 & Preponderantly stable conditions, there must be monitoring \\
\hline 6 & 10 & Preponderantly stable conditions, there must be monitoring \\
\hline 7 & 12.5 & Potentially unstable conditions \\
\hline 8 & 12.5 & Potentially unstable conditions \\
\hline 9 & 10.5 & Preponderantly stable conditions, there must be monitoring \\
\hline 10 & 10 & Preponderantly stable conditions, there must be monitoring \\
\hline 11 & 14 & Potentially unstable conditions \\
\hline 12 & 12.5 & Potentially unstable conditions \\
\hline 13 & 12.5 & Potentially unstable conditions \\
\hline 14 & 9 & Preponderantly stable conditions, there must be monitoring \\
\hline 15 & 15 & Potentially unstable conditions \\
\hline 16 & 10 & Preponderantly stable conditions, there must be monitoring \\
\hline
\end{tabular}

\section{Slip susceptibility analysis (the maximum water saturation value)}

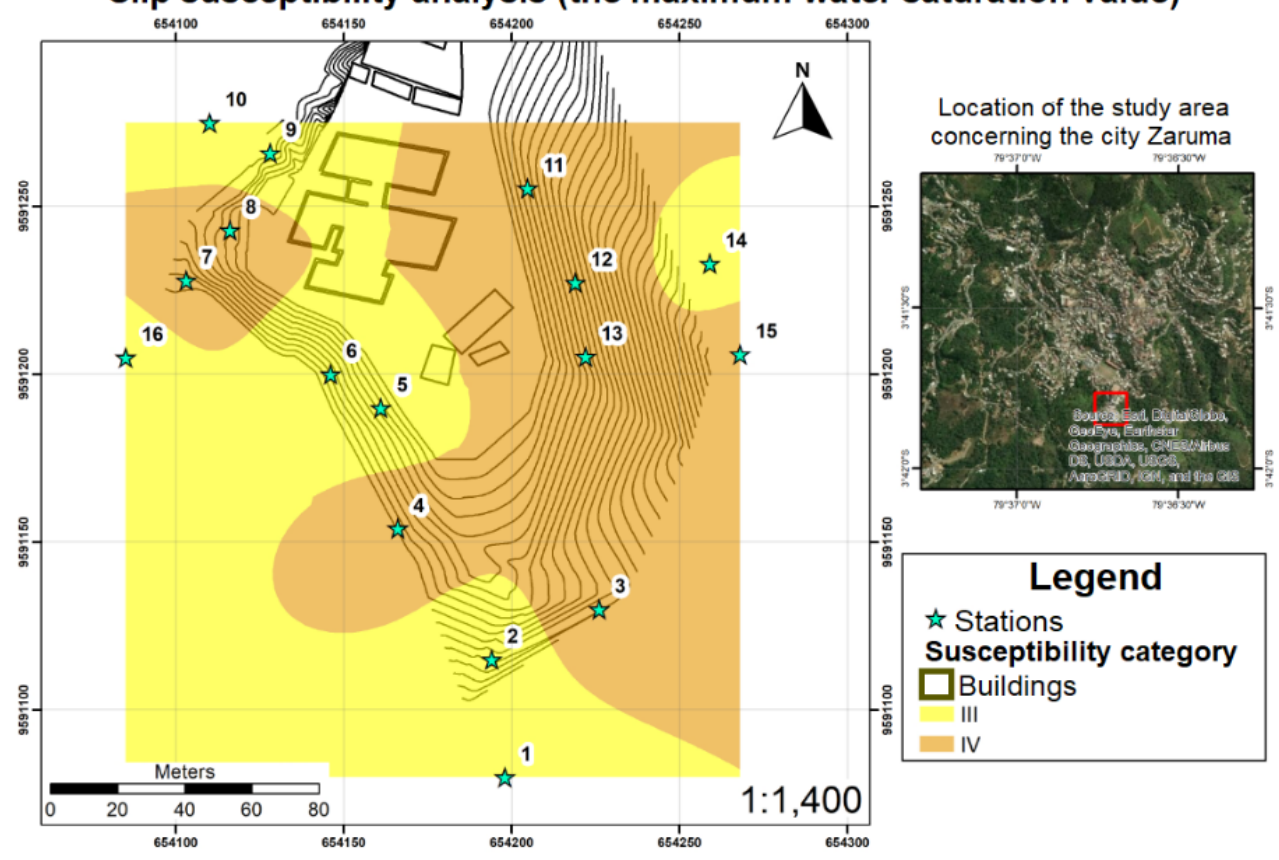

Figure 9: Slippage susceptibility map for a maximum water saturation value. 


\section{ANALYSIS OF RESULTS}

Relating all the data obtained in the studies carried out in the area (Table 3), it was determined that the lowest values in resistivity coincide with the filler area located west of the hospital and the area on the east side coincides with the slope and erosion values. These, in turn, coincide with areas vulnerable to slippage in the maximum condition of water saturation. If the safety factor calculation profiles are analyzed, values greater than 1 are considered stable, but according to the Ecuadorian construction standard for hospitals, a value less than 1.5 is considered unstable. However, according to the European University Laureate, if it implies losses of human lives, the minimum safety factor should be 1.7. In geophysics, the highest resistivity values correspond to areas that have stable weighted conditions, with safety factors greater than 1.5 based on the profiles made, which are located near the flat surface of the hospital terrace, that is, they are stable surfaces. This demonstrates that they cannot make slippage near the area of the Humberto Molina hospital buildings (Table 4).

Table 4: Correlation and interpretation of studies conducted in the area.

\begin{tabular}{|c|c|c|c|c|}
\hline $\begin{array}{c}\text { Resistivity } \\
(\Omega \mathrm{m})\end{array}$ & Interpretation & Drillings & S. S & Profiles (S. F) \\
\hline $1-7$ & Soil/Filler & & Unstable & S.F $<1.5$ \\
\hline $7-25$ & $\begin{array}{l}\text { Very saturated } \\
\text { saprolite }\end{array}$ & $\begin{array}{l}\text { Very saturated } \\
\text { saprolite }\end{array}$ & Unstable & S.F $<1.5$ \\
\hline 25-80 & Saturated saprolite & $\begin{array}{l}\text { Saturated } \\
\text { saprolite }\end{array}$ & Unstable & S.F $<1.5$ \\
\hline 80-200 & $\begin{array}{l}\text { Slightly saturated } \\
\text { saprolite }\end{array}$ & & Stable & S.F $>1.5$ \\
\hline $200-550$ & Fractured saprolite & & Stable & S.F $>1.5$ \\
\hline $550-850$ & Saprolite & & Stable & S.F $>1.5$ \\
\hline
\end{tabular}

\section{CONCLUSIONS}

From the campaigns carried out of vertical electrical surveys, electrical tomographies, drillings, and calicatas, the thickness of the underground geological structures was determined, recognizing and distinguishing the different layers corresponding to a fully weathered saprolite, of shades that vary from light brown to reddish, fine to coarse granulometry, presence of subvertical fractures oxidized fill and centimeter separations, with saturation percentage greater than $40 \%$ in most cases. With the help of the correlation of the existing perforations and those made in this investigation, it has been interpreted that the saprolite layer overlaps volcanoclastic rocks of thicknesses between 15 and $20 \mathrm{~m}$ and this, in turn, is overlying volcanic rocks, mainly andesite's of thicknesses between 20 and $30 \mathrm{~m}$.

In the case of lifting existing tunnels, it was possible to lift a tunnel approximately $25 \mathrm{~m}$ deep with an $\mathrm{N} 120^{\circ}$ direction, determining its lithology as a fractured saprolite with three main families of discontinuities that present directions of $\mathrm{N} 3^{\circ} / 78^{\circ} \mathrm{SE}, \mathrm{N} 202^{\circ} / 34^{\circ} \mathrm{NW}$, $\mathrm{N} 98^{\circ} / 80^{\circ} \mathrm{SW}$, decimetric separations and centimeter fillings. Also, it was possible to determine using field observations the boundary between filler material and saprolite, with direction $\mathrm{N} 203^{\circ} / 73^{\circ} \mathrm{SE}$. 
The study area is characterized by being a terrace surrounded by slopes of low to steep slopes (from $10^{\circ}$ to over $45^{\circ}$ ), abundant vegetation on all slopes works as good support for possible slippages, and based on this study the following characteristics were determined: the soil studied was categorized as very good to medium quality, and in a specific sector (station 15) it was categorized a little unstable. In general, the soil is plastic, with good consolidation and in other sectors, it is usually degradable but also with good compaction. It is estimated that water filtration is good since only superficially wet soils could be determined.

Considering the seismic coefficient of Zaruma, the safety factor in the SLIDE software was calculated, obtaining a value of 1.168, which is considered stable under normal conditions, according to Morante et al. [14]. But according to the standards established in case of human losses and considering the case of the hospital, the safety factor values considered stable are greater than 1.5. However, with the information analyzed in geophysics and the soil quality parameter in the susceptibility analysis, the material found in the subsoil is of good quality. If some type of landslide were produced, these would be superficial, of small magnitude and not in the surroundings.

The results and recommendations, if applied, give a solution and an aid to the Geopark project Ruta del Oro, which is carried out in this mining district Zaruma-Portovelo, as it has been proposed [15].

\section{RECOMMENDATIONS}

- A more regional study is recommended as this study limits the area of analysis.

- Due to the susceptibility analysis, it is recommended to carry out the control of rainwater drainage through ditches and drainage pipes, since it is known that the slope consists of filled materials (pushed to the slope), also to the control of the sewage water.

- It is important to change the type of existing filling with a sandy aggravated material, which must be well compacted and rammed, for the replacement of the concrete layer and the new tiles.

- The cracks and fissures in the staircase walls can be sealed by performing an old concrete chopping job, placing a $4.5 \mathrm{~mm}$ mesh fixed to steel nails, Fisher studs, and bolts. Place a layer of concrete with adherent additive $5 \mathrm{~cm}$ thick, which establishes to have two surfaces of $2.30 \times 4.30$. This is to prevent water from infiltrating the material, due to the cracks in the staircase walls.

- It is recommended to demolish existing small slabs, dig loose material approximately $0.5 \mathrm{~m}$, replenish this layer making a mixture of cement and soil, compacting it and ramming said mixture, on this surface the new tiles can be built with concrete of $180 \mathrm{Kg} / \mathrm{cm}^{2}$.

\section{ACKNOWLEDGEMENTS}

The authors acknowledge CIPAT-ESPOL for the logistics provided for the preparation of this work and the data obtained in the project "Analysis of the vulnerability to geodynamic risks and preparation of proposals for mitigation measures to increase safety conditions in the Humberto Molina Hospital and the San Juan Bosco School, Zaruma, El Oro province". To Zaruma Municipality for the availability and collaboration during the entire investigation process. 


\section{REFERENCES}

[1] González de Vallejo, L., Ferrer, M., Ortuño, L. \& Oteo, C. (eds), Ingeniería Geológica, Prentice Hall-Pearson Educación: Madrid, 2002.

[2] Valiente, S., Sobrecases, S. \& Díaz, A., Estabilidad de Taludes: Conceptos Básicos, Parámetros de Diseño y Métodos de Cálculo. Civilizate, 29(7), pp. 50-54, 2016.

[3] Gallardo, R., Guerrero, T. \& Macgregor, A., Investigación Geotécnica para la estabilización de las laderas del Barrio San Fermín, municipio de Ocaña, departamento de Norte de Santander (Colombia). Inge Cu, 9(2), pp. 66-74, 2013.

[4] Campoverde, C., Noriega, R., Carrión, P., Pindo, J., Recalde, E. \& Morante, F., Análisis de subsidencia por la actividad minera en la ciudad de Zaruma, patrimonio del Ecuador. Caso de estudio Escuela La Inmaculada. XVII Congreso Internacional sobre Patrimonio Geológico y Minero (29th ed.), 2017.

[5] Zha, J. \& Xu, M., High-grade highways deformation and failure laws in mining area: A case in Nantun Coal Mine, China. International Journal of Pavement Engineering, 20(11), pp. 1251-1263, 2017.

[6] Illinois Department of Natural Resources, Panorama Minero del Estado de Hidalgo. www.sgm.gob.mx/pdfs/HIDALGO.pdf. Accessed on: 6 Jan. 2019.

[7] Panorama Minero de los Estados SGM, Abandoned Mine Lands. Subsidence. www.dnr.illinois.gov/mines/AML/Pages/Subsidence.aspx. Accessed on: 6 Jan. 2019.

[8] El Confidencial, La ciudad que va a ser trasladada íntegra tres kilómetros al este: así lo harán. www.elconfidencial.com/alma-corazon-vida/2016-05-28/kiruna-sueciaurbanismo-subsidencia_1205591/. Accessed on: 7 Nov. 2019.

[9] La minería marcó la historia de Zaruma; El telégrafo website. www.eltelegrafo.com.ec/noticias/septimo/1/un-rincon-alberga-el-esplendor-de-laera-minera-en-zaruma. Accessed on: 4 Nov. 2019.

[10] El telégrafo, 59 kilómetros de galerías surcan las entrañas de Zaruma. www.elcomercio.com/actualidad/zaruma-galerias-mineria-oro-estadodeexcepcion. html. Accessed on: 10 Nov. 2019.

[11] Montalván, A., Informe de características sociales en el sector de estudio. inmediaciones del HB Dr. Humberto Molina y la parroquia de Zaruma. Ecuador, unpublished.

[12] Cobos, L., Yánez, D. \& Flores, J. Análisis de estabilidad y evaluación estructural del hospital básico Humberto Molina de la ciudad de Zaruma, provincia de El Oro (No. SGR-IASR-08-0166), unpublished.

[13] ESPOL Polytechnic University, Evaluación de amenazas geodinámicas en el entorno de la actividad minera en la concesión minera Palacios, thesis. www.dspace.espol.edu.ec/handle/123456789/46864. Accessed on: 10 Jan. 2020.

[14] Morante, F. et al., Evaluation of slope stability considering the preservation of the general patrimonial cemetery of Guayaquil, Ecuador. Geosciences, 9(3), p. 103, 2019.

[15] Carrión, P., Herrera, G., Briones, J., Caldevilla, P., Domínguez, M. \& Berrezueta, E., Geotourism and local development based on geological and mining sites utilization, Zaruma-Portovelo, Ecuador. Geosciences, 8(6), p. 205, 2019. 